\title{
Foliar Application of Biofilm Formation-Inhibiting Compounds Enhances Control of Citrus Canker Caused by Xanthomonas citri subsp. citri
}

\author{
Jinyun Li and Nian Wang \\ Citrus Research and Education Center, Department of Microbiology and Cell Science, University of Florida, IFAS, 700 Experiment Station \\ Road, Lake Alfred 33850. \\ Accepted for publication 25 July 2013.
}

\begin{abstract}
Li, J., and Wang, N. 2014. Foliar application of biofilm formationinhibiting compounds enhances control of citrus canker caused by Xanthomonas citri subsp. citri. Phytopathology 104:134-142.

Citrus canker caused by the bacterium Xanthomonas citri subsp. citri is an economically important disease of citrus worldwide. Biofilm formation plays an important role in early infection of X. citri subsp. citri on host leaves. In this study, we assessed the hypothesis that small molecules inhibiting biofilm formation reduce $X$. citri subsp. citri infection and enhance the control of citrus canker disease. D-leucine and 3 -indolylacetonitrile (IAN) were found to prevent biofilm formation by $X$. citri subsp. citri on different abiotic surfaces and host leaves at a

concentration lower than the minimum inhibitory concentration (MIC). Quantitative reverse transcription-polymerase chain reaction (qRT-PCR) analysis indicated that IAN repressed expression of chemotaxis/motilityrelated genes in $X$. citri subsp. citri. In laboratory experiments, planktonic and biofilm cells of $X$. citri subsp. citri treated with D-leucine and IAN, either alone or in combination, were more susceptible to copper $\left(\mathrm{CuSO}_{4}\right)$ than those untreated. In greenhouse assays, D-leucine and IAN applied alone or combined with copper reduced both the number of canker lesions and bacterial populations of $X$. citri subsp. citri on citrus host leaves. This study provides the basis for the use of foliar-applied biofilm inhibitors for the control of citrus canker alone or combined with copperbased bactericides.
\end{abstract}

Citrus canker, caused by the gram-negative bacterial pathogen Xanthomonas citri subsp. citri (syn. X. citri, X. campestris pv. citri, and $X$. axonopodis pv. citri) $(6,30,34)$, is one of the major constraints to citrus production worldwide $(10,12)$. Citrus canker affects most commercial citrus varieties and is widely distributed in many tropical and subtropical citrus growing regions $(10,12)$. Characteristic citrus canker symptoms include raised necrotic lesions surrounded by oily, water-soaked margins and yellow chlorotic rings on leaves, stems, and fruit of infected trees; and when conditions are highly favorable for disease, it also causes defoliation, twig dieback, general tree decline, blemished fruit, and premature fruit drop $(10,12)$. Wind-blown rain, which facilitates invasion via stomata or wounds (12), is the primary shortdistance (i.e., within the same tree or between neighboring trees) spread mechanism for citrus canker (9). Long-distance dissemination of the disease often occurs with the transportation of diseased propagating materials and infected fruit (9). Direct cankerrelated losses are attributed to the decrease of fruit quality and yield. Moreover, a serious consequence is the significant impact on commerce resulting from restrictions to national and international citrus trade from canker-affected areas $(10,12,31)$.

Copper-based bactericides are currently the primary control measure for citrus canker worldwide, as limited strategies exist for suppression of citrus canker on susceptible cultivars once the pathogen has been established $(10,12)$. For effective disease control, multiple applications of copper-based bactericides are needed throughout the year due to their partial effectiveness under wind-

Corresponding author: N. Wang; E-mail address: nianwang@ufl.edu

* The $\boldsymbol{e}$-Xtra logo stands for "electronic extra" and indicates that the online version contains one supplemental figure. Figures 2 and 5 appear in color online.

http://dx.doi.org/10.1094/PHYTO-04-13-0100-R

(c) 2014 The American Phytopathological Society blown rain conditions $(2,11)$. As a consequence, long-term use of copper bactericides led to resistance to copper in xanthomonad populations $(3,26)$ and the accumulation of copper metal in soils or ground water affecting the environment and plant health $(1,39)$. Thus, it is desired to reduce the usage of copper bactericides. A potential approach is to develop compounds that reduce bacterial resistance to copper bactericides and thereby enhancing the bactericidal effect and reducing the application of copper.

Much effort has been made to understand the biology and molecular basis of $X$. citri subsp. citri pathogenesis over the past decade $(5,7,18,38)$. The canker bacterium, considered to be a hemibiotrophic pathogen, initially grows epiphytically (on leaf surfaces) and then enters into the host through stomata or wounds to colonize the mesophyll parenchyma and multiply in the apoplast (intercellular spaces). X. citri subsp. citri, like many other plantpathogenic bacteria, has evolved multiple virulence factors to promote infection and establish themselves successfully in host plants $(18,38)$. Among the virulence factors important for $X$. citri subsp. citri infection, biofilms have been suggested to play an important role in the early stages of infection by enhancing epiphytic persistence on host leaves. Importantly, multiple mutants of $X$. citri subsp. citri impaired in biofilm formation consistently exhibit a decrease in bacterial growth in planta and have reduced ability to elicit canker symptoms in susceptible citrus leaves $(8,9$, $13,20,25,37)$. This led us to hypothesize that compounds inhibiting biofilm formation by $X$. citri subsp. citri may reduce its infection and enhance the control of canker disease. The goal of this study was thus twofold. First, we intended to identify small molecules that inhibit $X$. citri subsp. citri biofilm formation. Second, we aimed to determine if the selected biofilm formation inhibitors could increase the control effect of copper bactericides or reduce the usage of copper bactericides.

Here, we investigated the activity against $X$. citri subsp. citri biofilm formation of two sets of compounds, D-amino acids and 
indole derivatives, which have been shown to inhibit biofilm formation and influence virulence in human bacterial pathogens such as Escherichia coli O157:H7, Pseudomonas aeruginosa, and Staphylococcus aureus $(17,19)$. We provided evidence that D-leucine and 3-indolylacetonitrile (IAN) are active in inhibiting biofilm formation by $X$. citri subsp. citri in nutrient broth (NB) liquid medium at a concentration lower than the minimum inhibitory concentration (MIC). Moreover, we found that D-leucine and IAN increased the sensitivity of $X$. citri subsp. citri to copper and reduced symptom development and bacterial populations on citrus leaves in greenhouse. These results provided the basis for the use of foliar-applied biofilm inhibitors for the control of citrus canker alone or combined with copper-based bactericides.

\section{MATERIALS AND METHODS}

Bacterial strains and culture conditions. $X$. citri subsp. citri strain 306 (rifamycin [Rif] resistant [29]; copper sensitive, $\mathrm{Cu}^{\mathrm{S}}$ [4]) was used throughout this study. X. citri subsp. citri strain A44 (copper resistant, $\mathrm{Cu}^{\mathrm{R}}$ ) (4) was also used in the examination of bacterial resistance to copper with or without biofilm inhibitors. Nutrient agar (NA) and NB were used as the media for the growth of $X$. citri subsp. citri. The bacterium was initially streaked from $-80^{\circ} \mathrm{C}$ glycerol stock on an NA plate and a fresh single colony was inoculated in NB $(40 \mathrm{ml})$ in $150 \mathrm{ml}$ flasks and cultured at $28^{\circ} \mathrm{C}$ with agitation at $200 \mathrm{rpm}$. The overnight cultures were diluted in NB to standardize the cultures to obtain an optical density at $600 \mathrm{~nm}\left(\mathrm{OD}_{600}\right)$ of 1.0 prior to setting up the biofilm assay and cell growth measurements. When necessary, rifamycin was added in the medium at a final concentration of $50 \mu \mathrm{g} / \mathrm{ml}$.

Preparation of test compounds. D-amino acids (D-alanine, D-leucine, D-methionine, D-serine, D-tryptophan, and D-tyrosine) and indole derivatives (3-indoleacetic acid [IAA], IAN, and indole-3-propioninc acid [I3PA]) from plant sources were purchased from Sigma-Aldrich Co. (St. Louis, MO). The other chemicals including crystal violet (CV), ethyl alcohol, and dimethyl sulfoxide (DMSO) were purchased from Fisher Scientific Co. (Pittsburg, PA). Stock solutions $(500 \mathrm{mM}$ in sterilized distilled water [SDW] for D-amino acids; $5 \mathrm{mg} / \mathrm{ml}$ in $1 \%$ DMSO for indole derivatives) were filter sterilized and stored at $-20^{\circ} \mathrm{C}$ and diluted in SDW or DMSO for the initial test concentrations.

Evaluation of D-amino acids and indole derivatives for potential biofilm inhibition ability. A static biofilm formation assay in 96-well polystyrene plates coupled with CV staining was performed as previously reported with modifications (20). Briefly, a 96-well polystyrene plate (Nunclon surface, Nuncbrand, Denmark) was prepared with $170 \mu \mathrm{l}$ of NB plus $1.0 \%$ glucose per well. Aliquots of $20 \mu \mathrm{l}$ each of the different concentrations of the tested compound were pipetted into eight wells containing $170 \mu \mathrm{l}$ of NB plus $1.0 \%$ glucose. To each of these wells, $10 \mu \mathrm{l}$ of the standardized overnight $X$. citri subsp. citri strain 306 culture $\left(\mathrm{OD}_{600}=1.0\right)$ was added. Control wells contained NB plus $1.0 \%$ glucose and SDW or $0.1 \%$ DMSO as a sterility control, or standardized overnight $X$. citri subsp. citri strain 306 culture as a growth control. The plate was covered by a MicroWell lid (Nunclon), sealed with parafilm to prevent evaporation, and incubated at $28^{\circ} \mathrm{C}$ for $48 \mathrm{~h}$ without shaking. After incubation, the planktonic growth was measured at $\mathrm{OD}_{600}$. To quantify the amount of biofilms formed on the surfaces of the wells, the culture was removed from the wells. After drying, the wells were washed twice with $200 \mu \mathrm{l}$ of SDW for $5 \mathrm{~min}$, allowed to dry, and then $200 \mu \mathrm{l}$ of $0.1 \% \mathrm{CV}$ was added. After $30 \mathrm{~min}$, the $\mathrm{CV}$ was removed. The wells were washed with excess SDW to remove unbound CV and air dried in an inverted position for $2 \mathrm{~h}$. Afterward, $200 \mu \mathrm{l}$ of $95 \%$ ethanol was added to the wells and incubated for $30 \mathrm{~min}$ at room temperature to elute bound $\mathrm{CV}$. The eluted $\mathrm{CV}$ was twofold diluted in double distilled water and the absorbance at $590 \mathrm{~nm}$ was measured. Each data point was averaged from eight replicate wells.
To gain further evidence of the effect of selected compounds on biofilm formation, biofilm formation in glass tubes and on leaf surfaces was examined as described previously (21). Briefly, the standardized overnight cultures of $X$. citri subsp. citri strain 306 $\left(\mathrm{OD}_{600}=1.0\right)$ were diluted $1: 10$ in fresh NB containing $1.0 \%$ glucose and the selected compound. For biofilm formation assay in glass tubes (Fischer Scientific), $1 \mathrm{ml}$ of the diluted bacterial suspension was transferred into each sterilized borosilicate glass tube and incubated at $28^{\circ} \mathrm{C}$ without shaking for $48 \mathrm{~h}$. The planktonic growth was then discarded and the tubes were gently washed three times with SDW. The biofilm formed on the tubes was visualized by staining with $0.1 \% \mathrm{CV}$. The stain remaining in cells on glass tubes was dissolved in $95 \%$ ethanol and quantified by measuring the optical density at $590 \mathrm{~nm}$. For biofilm formation assay on leaf surfaces, $20 \mu \mathrm{l}$ of the diluted bacterial suspension was dropped onto the abaxial surface of citrus leaves. The leaves were kept in a humidified chamber at $28^{\circ} \mathrm{C}$ for $24 \mathrm{~h}$ without shaking. The biofilm formed on the leaf surfaces was visualized by staining with $0.1 \% \mathrm{CV}$. The biofilm assays were repeated three times with four replicates each time.

Determination of MICs. $X$. citri subsp. citri was grown in NB at $28^{\circ} \mathrm{C}$ with shaking at $200 \mathrm{rpm}$ for $7 \mathrm{~h}$. The cultures were standardized to an $\mathrm{OD}_{600}$ of $0.03\left(5 \times 10^{7}\right.$ colony forming unit $[\mathrm{CFU}] / \mathrm{ml}$ ) in NB and then aliquoted into wells of a 96-well plate, $190 \mu \mathrm{l}$ per well. The initial test concentrations of the compounds were diluted (1:20) in the culture (10 $\mu \mathrm{l}$ of compound in $190 \mu \mathrm{l}$ of culture) and incubated at $28^{\circ} \mathrm{C}$ under stationary conditions. The cultures were monitored at 24 and $48 \mathrm{~h}$ at $\mathrm{OD}_{600}$, and the lowest concentration resulting in no growth after $48 \mathrm{~h}$ compared with the control samples was defined as the MIC for X. citri subsp. citri. All determinations were conducted in eight replicate wells and repeated three times.

Evaluation of resistance of $X$. citri subsp. citri biofilm cells to copper. The level of copper resistance of biofilms was evaluated using a cell viability assay. Briefly, $X$. citri subsp. citri biofilms were prepared using NB with stationary incubation in glass tubes as described above. After $48 \mathrm{~h}$ incubation, the cultures were removed and bacterial cells attached to the tubes were gently washed three times with SDW. One milliliter of fresh NB with $\mathrm{CuSO}_{4}(1.0 \mathrm{mM})$, D-leucine $(10 \mathrm{mM})$, or IAN $(100 \mu \mathrm{g} / \mathrm{ml})$, or a combination of these compounds was added to each tube. NB alone was used as control. Tubes were kept at room temperature for $24 \mathrm{~h}$ followed by shaken vigorously for $5 \mathrm{~min}$. The suspensions were diluted in 10-fold series, and $10 \mu \mathrm{l}$ of each dilution was spotted in triplicate on NA plate. Plates were incubated at $28^{\circ} \mathrm{C}$ for 48 to $72 \mathrm{~h}$ prior to assessing bacterial growth. Colonies that grew near the dilution end-point were counted and bacterial populations in the initial suspensions prior to dilution were calculated. Each treatment comprised four replicates and the experiment was repeated three times.

RNA preparation and quantitative reverse transcriptionpolymerase chain reaction (qRT-PCR). $X$. citri subsp. citri was cultured in NB medium with or without biofilm inhibitor (IAN [100 $\mu \mathrm{g} / \mathrm{ml}]$ or D-leucine $[10 \mathrm{mM}])$ at $28^{\circ} \mathrm{C}$ without shaking. Cells were collected after $48 \mathrm{~h}$ of incubation by centrifugation at $12,000 \times g$ for $5 \mathrm{~min}$ at $4^{\circ} \mathrm{C}$ and used for RNA extraction. For the analysis of gene expression in $X$. citri subsp. citri planktonic and biofilm cells treated with sub-MICs concentrations of $\mathrm{CuSO}_{4}$ (0.1 mM for $X$. citri subsp. citri strain $306 ; 0.5 \mathrm{mM}$ for $X$. citri subsp. citri strain A44), we followed the same procedure described for evaluation of resistance of $X$. citri subsp. citri biofilm cells to copper in glass tubes. Both biofilm cells attached to the glass tube at the medium-air interface and planktonic cells in culture were collected. Cells collected after $48 \mathrm{~h}$ of incubation in the presence of $\mathrm{CuSO}_{4}$ were washed by centrifugation at $12,000 \times \mathrm{g}$ for $5 \mathrm{~min}$ at $4{ }^{\circ} \mathrm{C}$ with diethylpyrocarbonate-treated water. Cells collected from five tubes were combined and served as one biological replicate. The pellet was stored at $-80^{\circ} \mathrm{C}$ until RNA 
extraction. Total RNA of $X$. citri subsp. citri cells was isolated using RNA protect bacterial reagent (Qiagen, Valencia, CA) and RNeasy Mini Kit (Qiagen), following the manufacturer's instructions. Genomic DNA was removed using a TURBO DNA-free kit (Ambion, Austin, TX). RNA purity and quality were evaluated with a NanoDrop ND-1000 spectrophotometer (NanoDrop Technologies, Wilmington, DE).

A one-step qRT-PCR was conducted using a 7500 fast real-time PCR system (Applied Biosystems, Foster City, CA) with a QuantiTect SYBR green RT-PCR kit (Qiagen) following the manufacturer's instructions. The gene specific primers (Table 1) were designed based on the genome sequence of $X$. citri subsp. citri strain 306 (7) and nucleotide sequence for copper resistance genes from $X$. citri subsp. citri strain A44 (4), respectively. In the biofilm inhibition mechanism studies, those primers targeted 15 genes that were previously identified to be related to biofilm formation in X. citri subsp. citri strain 306 (20). In the copper resistance analysis, those primers targeted the gum genes gumB and gumD, polysaccharides-related gene galU, lipopolysaccharide (LPS) O-antigen biosynthesis gene $r f b C$, and copper resistancerelated genes copA and $\operatorname{copB}(3,33)$. The DNA gyrase subunit A encoding gene $g y r A$ was used as endogenous control. The relative fold change in gene expression was calculated using the formula $2^{-\Delta \Delta \mathrm{CT}}$ (23). qRT-PCR was repeated twice with four independent biological replicates each time.
Plant test in greenhouse. The effect of selected biofilm inhibitors on $X$. citri subsp. citri infection/virulence was investigated using 20-week-old potted grapefruit (Citrus paradise 'Duncan' grapefruit) plants in a quarantine greenhouse at the Citrus Research and Education Center, Lake Alfred, FL. Copper $\left(\mathrm{CuSO}_{4}, 100 \mu \mathrm{g} / \mathrm{ml}\right)$, D-leucine $(10 \mathrm{mM}), \mathrm{IAN}(100 \mu \mathrm{g} / \mathrm{ml})$, and a combination of these compounds were individually prepared in $100 \mathrm{ml}$ of SDW. Bacterial inoculum was prepared by growing $X$. citri subsp. citri strain 306 on NA plates at $28^{\circ} \mathrm{C}$ for $48 \mathrm{~h}$, suspending in SDW, and adjusting concentration to approximately $\mathrm{OD}_{600}=0.3\left(5 \times 10^{8} \mathrm{CFU} / \mathrm{ml}\right)$. The inoculation was performed by a spray method as described previously (21) with modifications. Briefly, the abaxial surfaces of fully expanded, immature leaves of each plant were sprayed with the following treatments: SDW, $X$. citri subsp. citri strain 306, and X. citri subsp. citri strain 306 combined with $\mathrm{CuSO}_{4}(100 \mu \mathrm{g} / \mathrm{ml})$, D-leucine $(10 \mathrm{mM})$, IAN $(100 \mu \mathrm{g} / \mathrm{ml})$, or a combination of these compounds. Silwett-L77 (silicone-polyether copolymer, Fisher Scientific) was added to each treatment at a $0.03 \%(\mathrm{vol} / \mathrm{vol})$ final concentration. After inoculation, the plants were covered with plastic bags for $24 \mathrm{~h}$ to maintain a high $(>90 \%)$ relative humidity and then kept in a greenhouse (approximately 60\% relative humidity) for symptom development. All inoculations included a minimum of three immature leaves at a similar developmental stage from each plant, and each treatment comprised four plants. The experiments were

TABLE 1. Genes and corresponding primers used in quantitative reverse transcription polymerase chain reaction (qRT-PCR)

\begin{tabular}{|c|c|c|c|}
\hline Gene & Locus_tag & Function of protein product & Primer sequence $\left(5^{\prime}-3^{\prime}\right)$ \\
\hline \multicolumn{4}{|c|}{ Xanthomonas citri subsp. citri strain 306} \\
\hline gumB & XAC2585 & EPS xanthan biosynthesis & $\begin{array}{l}\text { Forward: agaacggccatatttcgttg } \\
\text { Reverse: tgcagataaccgttgcgata }\end{array}$ \\
\hline gumD & XAC2583 & EPS xanthan biosynthesis & $\begin{array}{l}\text { Forward: tccgtaccccatacgacatt } \\
\text { Reverse: taccagcttgacgttgatcg }\end{array}$ \\
\hline galU & XAC2292 & Polysaccharides biosynthesis & $\begin{array}{l}\text { Forward: acagtgccgaaagaaatgct } \\
\text { Reverse: agctcataggccttgtcgaa }\end{array}$ \\
\hline$r f b C$ & XАC3598 & LPS O-antigen biosynthesis & $\begin{array}{l}\text { Forward: atcatcceggtctgcaatac } \\
\text { Reverse: ggaatgcgettcttgaactc }\end{array}$ \\
\hline cheA & XAC1930 & Chemotaxis protein & $\begin{array}{l}\text { Forward: gacgatattgctgccgattt } \\
\text { Reverse: gagctggtcggcttcttct }\end{array}$ \\
\hline cheY & XAC1904 & Bacterial chemotaxis regulator & $\begin{array}{l}\text { Forward: tacaagttcacccccatgct } \\
\text { Reverse: gcgatcagctgttctggatt }\end{array}$ \\
\hline$m c p A$ & XAC1746 & Chemotaxis protein & $\begin{array}{l}\text { Forward: cctatcgaacctgcttggac } \\
\text { Reverse: cacctcgtccagtcgatacc }\end{array}$ \\
\hline$m o t B$ & XAC1908 & Flagellar motor protein & $\begin{array}{l}\text { Forward: atctgtggatcgaggtggag } \\
\text { Reverse: gttcccagttggagggaaat }\end{array}$ \\
\hline fleN & XAC1934 & Flagellar biosynthesis & $\begin{array}{l}\text { Forward: agtctcgttcttcgecttga } \\
\text { Reverse: gttggtcagcttggcgtatt }\end{array}$ \\
\hline fliC & XAC1975 & Flagellar biosynthesis & $\begin{array}{l}\text { Forward: cagcgtattcgtgagctgtc } \\
\text { Reverse: ccgttgaagttggtctggtt }\end{array}$ \\
\hline pilB & XАC3239 & Pilus biogenesis & $\begin{array}{l}\text { Forward: caagtgctaccgctgttcaa } \\
\text { Reverse: gcgacggatctgatcttcat }\end{array}$ \\
\hline$c l p$ & XАC0483 & cAMP regulatory protein & $\begin{array}{l}\text { Forward: gaactaccatgagcccagga } \\
\text { Reverse: gccgctgatcacgtagtaga }\end{array}$ \\
\hline colR & XAC3250 & Response regulator & $\begin{array}{l}\text { Forward: ttggcgattacctcgaagac } \\
\text { Reverse: gttgaggtcgagcacgatg }\end{array}$ \\
\hline$r p f G$ & XAC1877 & Response regulator & $\begin{array}{l}\text { Forward: ggatctgggattgaacatcg } \\
\text { Reverse: agtccagcaacagcagatcc }\end{array}$ \\
\hline rpoN & XAC1969 & RNA polymerase sigma-54 factor & $\begin{array}{l}\text { Forward: gcttccatgaagacgaccat } \\
\text { Reverse: gctcttccaactccagcaac }\end{array}$ \\
\hline $\operatorname{cop} A$ & XAC3630 & Copper resistance protein & $\begin{array}{l}\text { Forward: cgatgtttcaggagcagtca } \\
\text { Reverse: tgtttcaaacgacggaacag }\end{array}$ \\
\hline $\operatorname{cop} B$ & XAC3631 & Copper resistance protein & $\begin{array}{l}\text { Forward: ctcaccgagacacgcactaa } \\
\text { Reverse: ccgatcgagcaggacataat }\end{array}$ \\
\hline gyrA & XAC1631 & DNA gyrase subunit A & $\begin{array}{l}\text { Forward: cgtcacgttgatccgttgt } \\
\text { Reverse: gettgettggtccactccct }\end{array}$ \\
\hline \multicolumn{4}{|c|}{ X. citri subsp. citri strain A44 } \\
\hline copA & & Copper resistance protein & $\begin{array}{l}\text { Forward: ctacttgatgaacggcacga } \\
\text { Reverse: aaccggatggacatacaagc }\end{array}$ \\
\hline $\operatorname{cop} B$ & & Copper resistance protein & $\begin{array}{l}\text { Forward: ctttacggccgcagtatctc } \\
\text { Reverse: gcggacacttcgaacttcat }\end{array}$ \\
\hline $\operatorname{copL}$ & & Transcriptional repressor & $\begin{array}{l}\text { Forward: gatcgtcatgctcgtgctta } \\
\text { Reverse: ctttcaatcgaggtggcatc }\end{array}$ \\
\hline
\end{tabular}


repeated three times independently. SDW and $X$. citri subsp. citri strain 306 mixed with SDW were used as controls. To determine whether the timing of application of biofilm inhibitors in relation to $X$. citri subsp. citri strain 306 affected canker symptom suppression, the biofilm inhibitors were inoculated on leaves $6 \mathrm{~h}$ prior to or after inoculation with $X$. citri subsp. citri strain 306.

For bacterial population assays, the leaves of grapefruit plants were inoculated as described above. Two leaf discs randomly selected from each of three inoculated leaves were cut with a cork borer $(0.8 \mathrm{~cm}$ in diameter) and then ground in $1 \mathrm{ml}$ of SDW. The suspensions were serially diluted and plated on NA plates containing rifamycin. After incubation at $28^{\circ} \mathrm{C}$ for $48 \mathrm{~h}$, bacterial colonies were counted and the number of CFU per square centimeter of leaf tissue was calculated. The assays were repeated three times independently.

\section{RESULTS}

D-leucine and IAN are potent biofilm inhibitors of $X$. citri subsp. citri. Six D-amino acids and three indole derivatives derived from plant sources were tested for their ability to inhibit biofilm formation of $X$. citri subsp. citri strain 306 in 96-well plate biofilm assays. In the absence of D-amino acid or indole derivative, $X$. citri subsp. citri strain 306 formed robust biofilms after $48 \mathrm{~h}$ of incubation (Fig. 1A). The addition of $10 \mathrm{mM}$ of D-leucine, D-serine, and $100 \mu \mathrm{g} / \mathrm{ml}$ IAN significantly reduced $X$. citri subsp. citri strain 306 biofilm formation by 45 to $68 \%$, whereas the other D-amino acids or indole derivatives tested did not affect $X$. citri subsp. citri strain 306 biofilm formation at the tested concentrations (Fig. 1A). Furthermore, the compounds D-leucine, D-serine, and IAN decreased $X$. citri subsp. citri strain 306 biofilm in a dose-dependent manner from 0 to $15 \mathrm{mM}$ for D-leucine and D-serine (Fig. 1B) and 0 to $150 \mu \mathrm{g} / \mathrm{ml}$ for IAN (Fig. 1C).

To test the toxicity of the three biofilm inhibitors, the MICs were determined in NB medium. The results showed that D-serine had the lowest MIC of $8.0 \mathrm{mM}$, followed by D-leucine and IAN with MICs of $16.0 \mathrm{mM}$ and $200 \mu \mathrm{g} / \mathrm{ml}$, respectively (Table 2). D-leucine and IAN had relatively high MICs but paradoxically demonstrated the potent decrease in biofilm mass $(58 \%$ decrease for D-leucine; $65 \%$ decrease for IAN) at lower concentrations than MICs (10 mM for D-leucine and $100 \mu \mathrm{g} / \mathrm{ml}$ for IAN) (Fig. 1A). Due to its low toxicity to X. citri subsp. citri strain 306 and

A

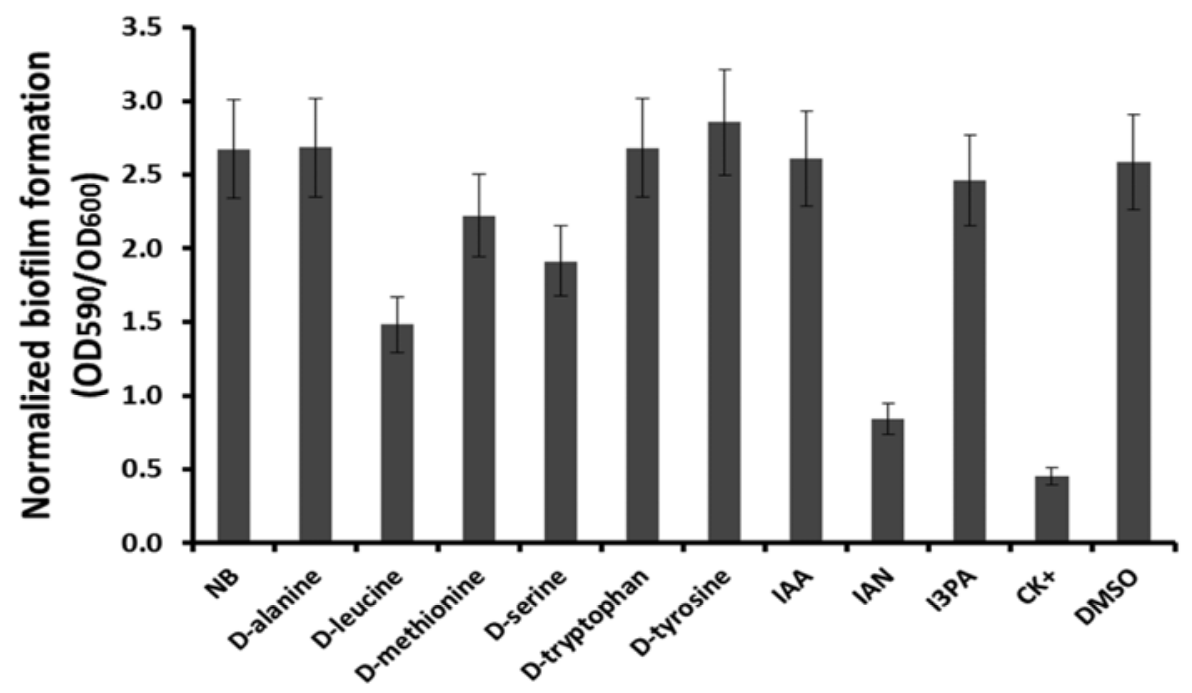

B

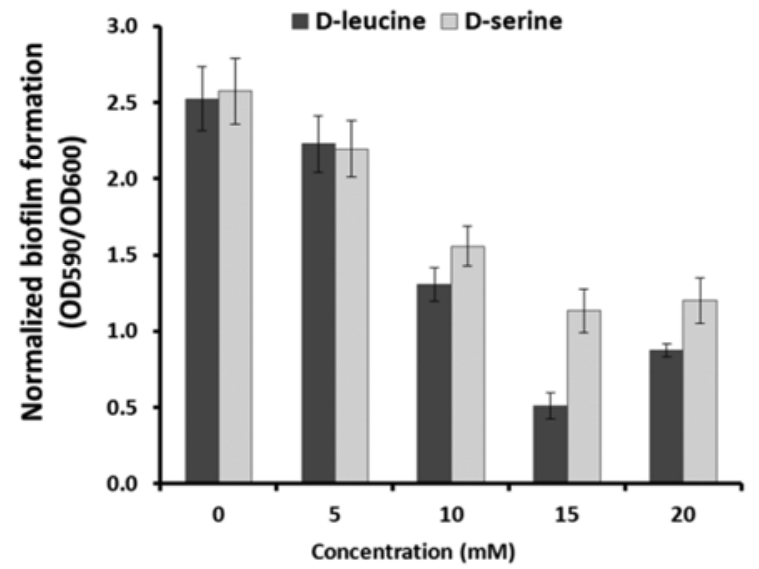

C

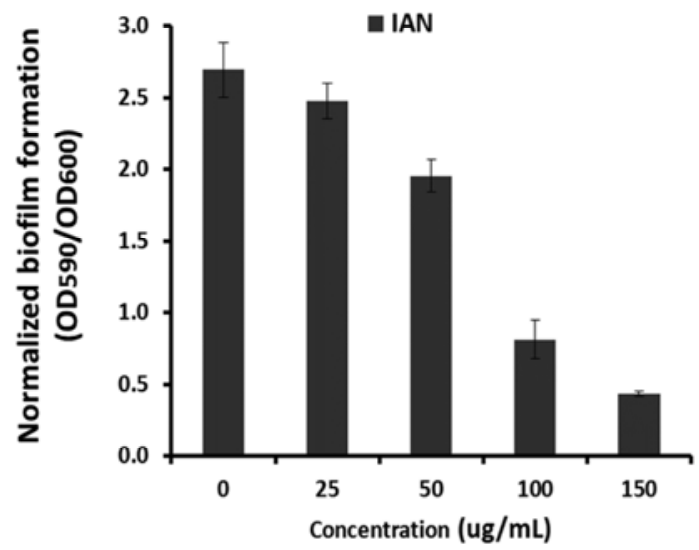

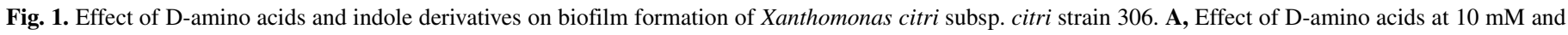

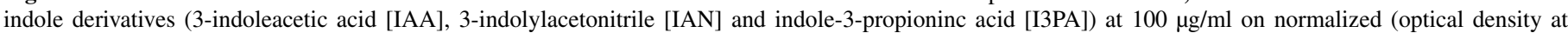

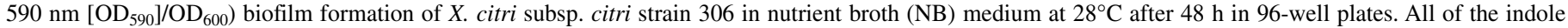

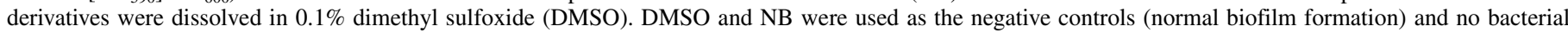

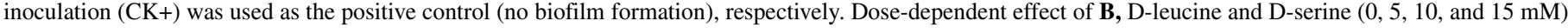

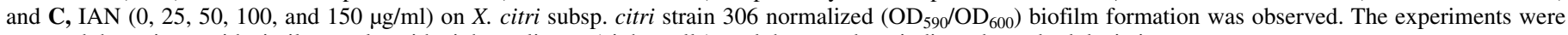
repeated three times with similar results with eight replicates (eight wells), and the error bars indicated standard deviations. 
apparent potency against biofilm formation, D-leucine and IAN were selected for further studies.

D-leucine and IAN reduce biofilm formation on abiotic surfaces and host leaves at sub-MIC concentrations. To further evaluate and confirm the antibiofilm properties of D-leucine and IAN, biofilm formation of $X$. citri subsp. citri strain 306 with the compounds at sub-MIC (10 mM for D-leucine and $100 \mu \mathrm{g} / \mathrm{ml}$ for IAN), a concentration that does not significantly decrease planktonic cell density (data not shown), was examined on three different kinds of surfaces: polystyrene, glass, and host leaves. The Dleucine- or IAN-treated cultures exhibited a significant reduction in biofilm formation both on polystyrene surface and in glass tubes compared with the untreated control, where the levels of biofilm formation were reduced to 50 and $60 \%$ of control, respectively (Fig. 2A and B). Similar to the observations on polystyrene surface and in glass tubes, the D-leucine- or IANtreated cultures showed declined biofilm formation on citrus leaf surfaces (Fig. 2C), suggesting that D-leucine and IAN reduced biofilm formation of $X$. citri subsp. citri strain 306 on citrus leaves. These findings confirmed that D-leucine and IAN had

TABLE 2. Minimum inhibitory concentrations (MICs) of copper $\left(\mathrm{CuSO}_{4}\right)$ against Xanthomonas citri subsp. citri strains 306 and A44 in nutrient broth medium with or without biofilm inhibitor ${ }^{\mathrm{a}}$

\begin{tabular}{lcc}
\hline & \multicolumn{2}{c}{ MIC $(\mathrm{mM})$} \\
\cline { 2 - 3 } Treatment & Xac 306 & Xac A44 \\
\hline $\mathrm{CuSO}_{4}$ & 0.5 & 2.5 \\
D-leucine & 16.0 & 20.0 \\
D-serine & 8.0 & $\mathrm{ND}$ \\
$\mathrm{IAN}$ & $200(\mu \mathrm{g} / \mathrm{ml})$ & $250(\mu \mathrm{g} / \mathrm{ml})$ \\
$\mathrm{CuSO}_{4} / \mathrm{D}-\mathrm{leucine}(10 \mathrm{mM})$ & 0.25 & 1.25 \\
$\mathrm{CuSO}_{4} / \mathrm{IAN}(100 \mu \mathrm{g} / \mathrm{ml})$ & 0.25 & 1.25 \\
$\mathrm{CuSO}_{4} / \mathrm{D}-\mathrm{leucine}(10 \mathrm{mM}) / \mathrm{IAN}(100 \mu \mathrm{g} / \mathrm{ml})$ & 0.25 & 1.25 \\
\hline
\end{tabular}

a The MICs were examined using a 96-well plate assay at $28^{\circ} \mathrm{C}$ under stationary conditions as described in the Materials and Methods. The MIC was defined as the lowest concentration resulting in no bacterial growth measured at optical density at $600 \mathrm{~nm}$ after a $48 \mathrm{~h}$ incubation compared with the control samples. ND: not determined. The determinations were repeated three times with eight replicate wells each time. specific activity inhibiting biofilm formation by $X$. citri subsp. citri strain 306.

Differential gene expression of $X$. citri subsp. citri strain 306 cells with IAN. To obtain insight into the mechanisms by which D-leucine and IAN inhibit biofilm formation, we evaluated the effect of these two compounds on expression of genes important for biofilm formation in X. citri subsp. citri strain 306 using qRTPCR. The selected genes included the gum genes gumB and gumD, polysaccharides-related gene galU, O-antigen biosynthesis gene $r f b C$, chemotaxis and motility genes cheA, cheY, mcpA, and $m o t B$, type IV twitching motility gene pilB, flagellar biosynthesis genes fleN and fliC, and regulator genes colR, clp, rpfG, and rpoN. In our previous studies, these genes were identified to be important for biofilm formation in X. citri subsp. citri strain 306 (20). The results showed that IAN significantly $(P<0.05$, Student $t$ test) repressed expression of chemotaxis and motility genes cheY, motB, and pilB, whereas D-leucine had no effect on expression of the tested genes (Fig. 3).

Suppression of $X$. citri subsp. citri resistance to copper by D-leucine and IAN. The copper resistance of planktonic cells of $X$. citri subsp. citri strain 306 was evaluated with and without biofilm inhibitor. In the NB medium, planktonic cells exhibited a MIC of $0.50 \mathrm{mM} \mathrm{CuSO}_{4}$ without biofilm inhibitor. In the presence of D-leucine, IAN or a combination of the two compounds at subMIC concentrations $(10 \mathrm{mM}$ for D-leucine and $100 \mu \mathrm{g} / \mathrm{ml}$ for IAN), the MICs of $\mathrm{CuSO}_{4}$ against $X$. citri subsp. citri strain 306 planktonic cells were decreased to $0.25 \mathrm{mM}$ (Table 2). Similar results were obtained with the $\mathrm{Cu}^{\mathrm{R}}$ strain $X$. citri subsp. citri strain A44. The MIC of $\mathrm{CuSO}_{4}$ alone against planktonic cells of A44 was $2.5 \mathrm{mM}$ in NB medium. In the presence of D-leucine, IAN or a combination of the two compounds at sub-MIC concentrations (10 $\mathrm{mM}$ for D-leucine and $100 \mu \mathrm{g} / \mathrm{ml}$ for IAN), the MICs were decreased to $1.25 \mathrm{mM}$ (Table 2). These results suggested that D-leucine and IAN increased the susceptibility of $X$. citri subsp. citri planktonic cells to copper under the applied conditions.

In the cell viability assays, biofilms treated with D-leucine, IAN, or a combination of the two compounds at sub-MIC concentrations ( $10 \mathrm{mM}$ for D-leucine and $100 \mu \mathrm{g} / \mathrm{ml}$ for IAN) were about 10 times more susceptible to $\mathrm{CuSO}_{4}$ than the untreated
A

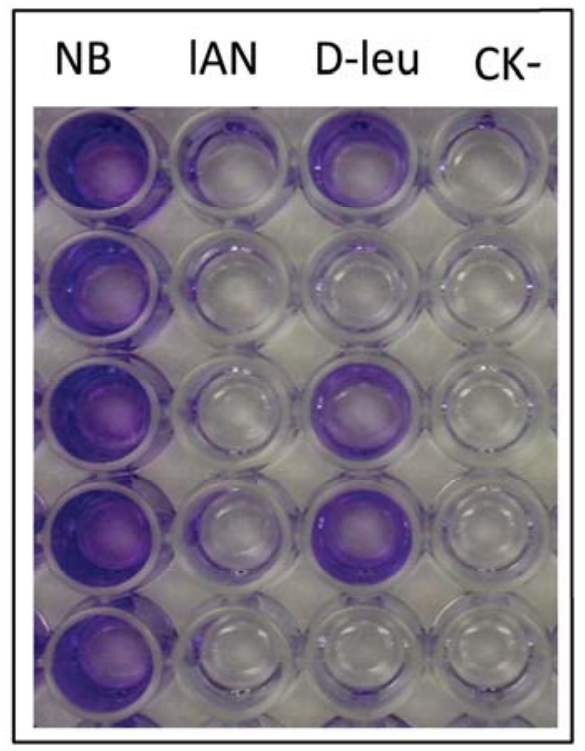

B

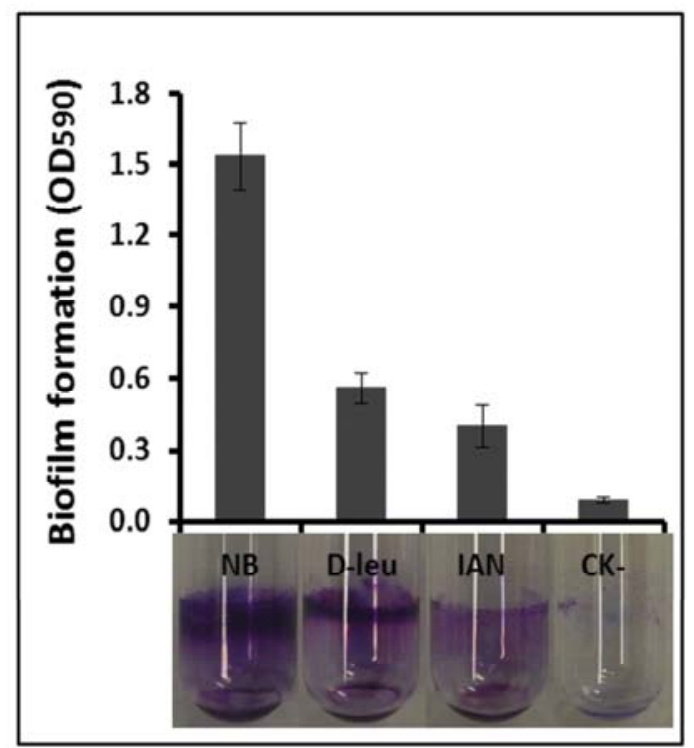

C

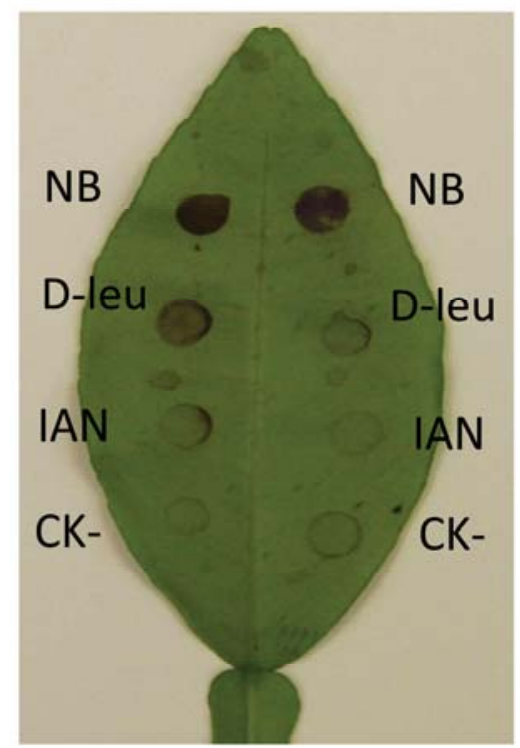

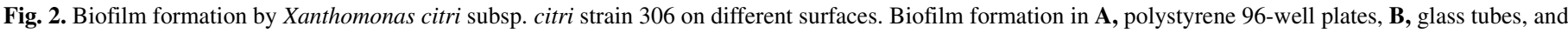

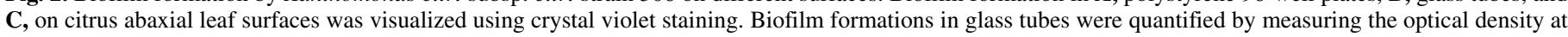

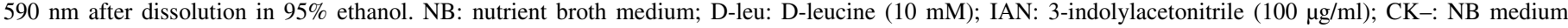

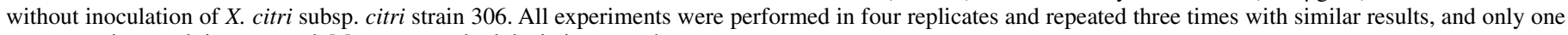
representative result is presented. Means \pm standard deviations are shown. 
control. The cell viability of $X$. citri subsp. citri biofilms exposed to $\mathrm{CuSO}_{4}$ (1.0 mM for $X$. citri subsp. citri strain $306 ; 2.0 \mathrm{mM}$ for $X$. citri subsp. citri strain A44) was significantly reduced by D-Leucine or IAN. Biofilms exposed to $\mathrm{CuSO}_{4}$ alone for $24 \mathrm{~h}$ contained an average of $3.0 \times 10^{7} \mathrm{CFU} / \mathrm{ml}$ for $X$. citri subsp. citri strain 306 and $1.3 \times 10^{8} \mathrm{CFU} / \mathrm{ml}$ for $X$. citri subsp. citri strain A44, respectively; while the biofilms treated by D-leucine $(10.0 \mathrm{mM})$, IAN $(100 \mu \mathrm{g} / \mathrm{ml})$, or a combination of the two compounds contained an average of $1.1 \times 10^{6}, 4.3 \times 10^{6}$, and $2.5 \times 10^{6}$ $\mathrm{CFU} / \mathrm{ml}$ (for $X$. citri subsp. citri strain 306) and $2.4 \times 10^{7}, 2.9 \times$ $10^{7}$, and $1.6 \times 10^{7} \mathrm{CFU} / \mathrm{ml}$ (for $X$. citri subsp. citri strain A44), respectively (Fig. 4). These findings indicated that D-leucine and IAN increased the susceptibility of $X$. citri subsp. citri biofilm cells to copper under the applied conditions.

To obtain insight into the mechanisms by which D-leucine and IAN increase the susceptibility of $X$. citri subsp. citri cells to copper, we evaluated the effect of the two compounds on expression of the polysaccharides-related gene galU, gum genes gumB and gumD, LPS O-antigen biosynthesis gene $r f b C$, and copper resistance related genes $\operatorname{cop} A$ and $\operatorname{cop} B$ in $X$. citri subsp. citri strain 306 planktonic and biofilm cells and expression of the copper resistance genes $\operatorname{cop} A, \operatorname{cop} B$, and $\operatorname{cop} L$ in $X$. citri subsp. citri strain A44 planktonic and biofilm cells, respectively. The qRT-PCR results showed that either D-leucine or IAN did not affect the expression of any of the genes tested in X. citri subsp. citri planktonic or biofilm cells in the presence of $\mathrm{CuSO}_{4}$ (Supplemental Figure 1).

D-leucine and IAN reduce canker symptom production and bacterial populations in planta. Plant inoculation by spray showed that both D-leucine $(10 \mathrm{mM})$ and IAN $(100 \mu \mathrm{g} / \mathrm{ml})$ were able to reduce canker symptom development on grapefruit leaves when applied along with or prior to the pathogen inoculation, as evidenced by decreased lesion numbers compared with the positive control (pathogen inoculation alone) (Fig. 5A). Differences in lesion numbers were notable by 14 days postinoculation and more distinctive over the remainder of the experiment. When applied after the pathogen inoculation, either D-leucine or IAN did not affect the development of canker symptoms (Fig. 5A). Both D-leucine and IAN could reduce the level of canker lesions to that of copper spray $\left(\mathrm{CuSO}_{4}, 100 \mu \mathrm{g} / \mathrm{ml}\right)$. The leaves sprayed with D-leucine $(10 \mathrm{mM})$, IAN $(100 \mu \mathrm{g} / \mathrm{ml})$, or $\mathrm{CuSO}_{4}(100 \mu \mathrm{g} / \mathrm{ml})$ displayed a similar level of canker lesions, less than those sprayed

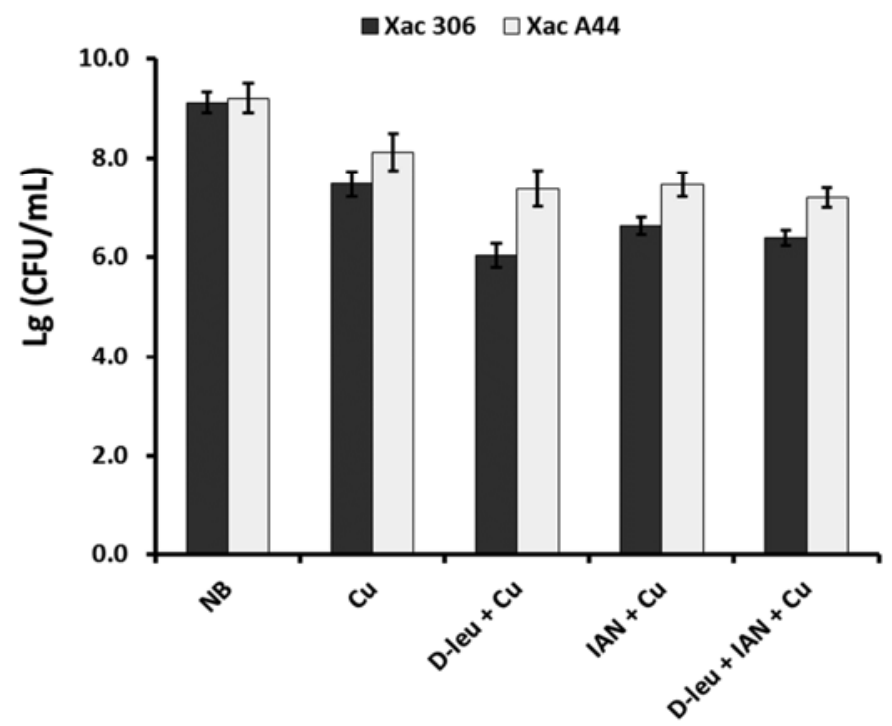

Fig. 4. Effect of D-leucine and 3-indolylacetonitrile (IAN) on cell viability of Xanthomonas citri subsp. citri strains 306 (Xac 306) and (Xac A44) in biofilms exposed to copper. Viable cells in biofilms exposed to the agent alone or in combination were quantified using the dilution-plating method. $\mathrm{Cu}$ : $\mathrm{CuSO}_{4}(1.0 \mathrm{mM}$ for strain $306 ; 2.0 \mathrm{mM}$ for strain A44); D-leu: D-leucine (10 $\mathrm{mM})$; IAN: 3-indolylacetonitrile $(100 \mu \mathrm{g} / \mathrm{ml})$; NB: nutrient broth medium alone. The experiments were repeated three times with similar results with four replicates. The error bars indicated standard deviations.

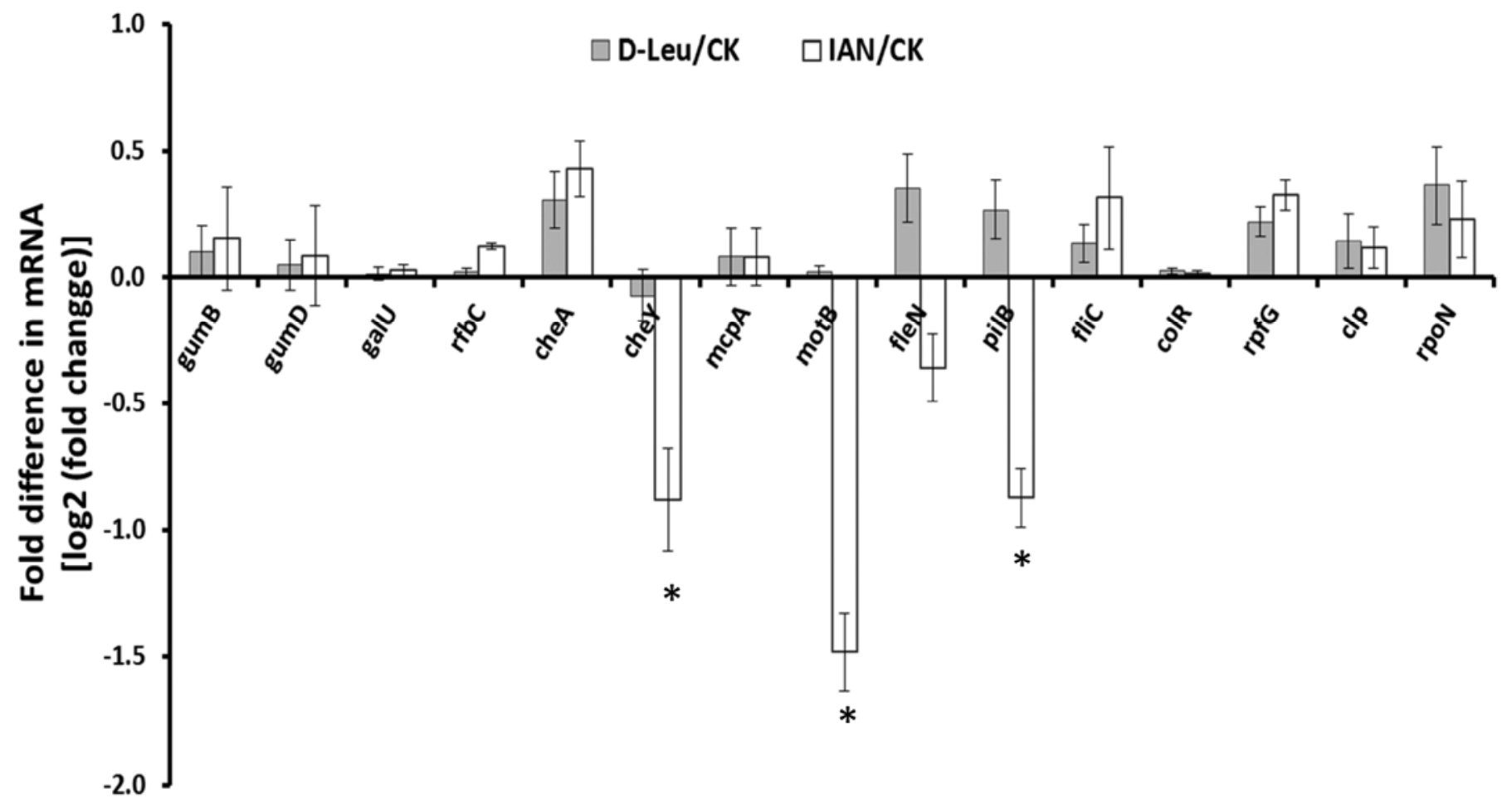

Fig. 3. Differential gene expression in Xanthomonas citri subsp. citri strain 306 cells in the presence of 3 -indolylacetonitrile (IAN) at $100 \mu \mathrm{g} / \mathrm{ml}$ as revealed by quantitative reverse transcription polymerase chain reaction (qRT-PCR) analysis. Data were presented as the ratio of transcript number in the treatment of IAN or D-leucine (D-Leu) compared with that in the untreated control (CK). gyrA was used as an endogenous control. The asterisk denotes $P<0.05(t$ test) compared with the untreated control. qRT-PCR was repeated twice with similar results with four independent biological replicates each time. 
with the pathogen alone (Fig. 5A). The combination of D-leucine $(10 \mathrm{mM})$, IAN $(100 \mu \mathrm{g} / \mathrm{ml})$, and $\mathrm{CuSO}_{4}(100 \mu \mathrm{g} / \mathrm{ml})$ was more effective in suppressing the development of canker symptoms than $\mathrm{CuSO}_{4}$ alone, with fewer lesions produced on the leaves (Fig. 5A). These visual observations correlated with bacterial populations recovered from the inoculated leaves after inoculation that revealed an approximately 10- to 100 -fold decrease in CFU per square centimeter of leaf tissue for treatment with D-leucine, IAN, or $\mathrm{CuSO}_{4}$, alone or in combination, compared with the untreated control (Fig. 5B). Treatment of the grapefruit leaves with D-leucine, IAN, or $\mathrm{CuSO}_{4}$ alone resulted in an approximate $1.0 \mathrm{log}$ reduction in the number of CFU compared with the untreated control, while treatment with a combination of D-leucine or/and $\mathrm{IAN}_{\text {and }} \mathrm{CuSO}_{4}$ resulted in an approximate $2.0 \mathrm{log}$ reduction in the number of CFU per square centimeter compared with the untreated control from 7 to 28 days after inoculation (Fig. 5B).

\section{DISCUSSION}

In this study, we demonstrated that D-leucine and IAN reduced biofilm formation by $X$. citri subsp. citri and increased the susceptibility of $X$. citri subsp. citri to copper at a concentration without affecting its growth. Canker control activity was evaluated as the ability to reduce the number of lesions and populations of $X$. citri subsp. citri on citrus leaves after applications. The results of these greenhouse assays support the use of foliar-applied biofilm inhibitors alone or combined with copper-based bactericides for the control of canker disease on citrus trees. These observations were similar to those described by Worthington et al. (35), which showed that a derivative from the small molecule 2-aminoimidazole (2AI) at nonbactericidal concentrations exhibited the antibiofilm property and enhanced control of copperresistant $X$. euvesicatoria on peppers by decreasing the resistance of X. euvesicatoria to copper. Interestingly, Palmer and colleagues

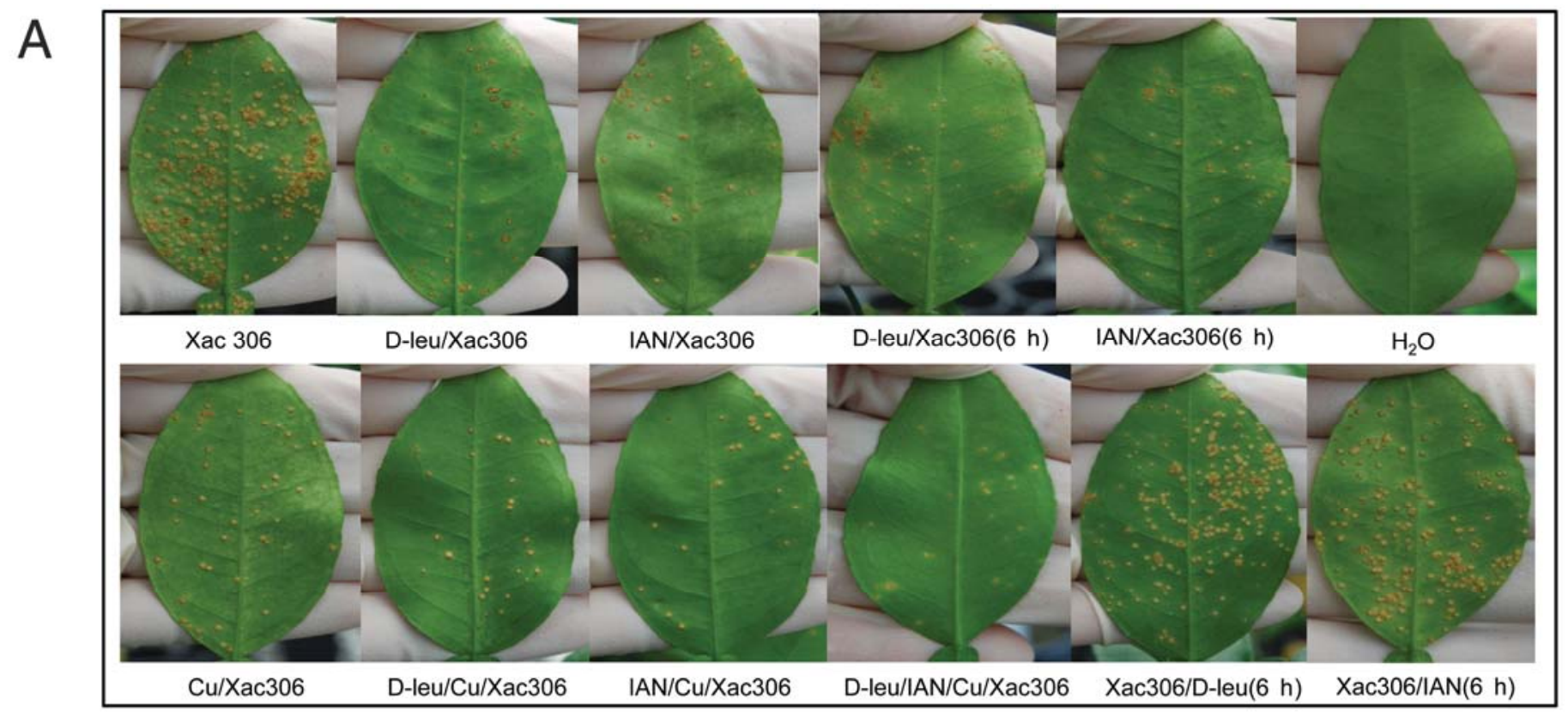

B

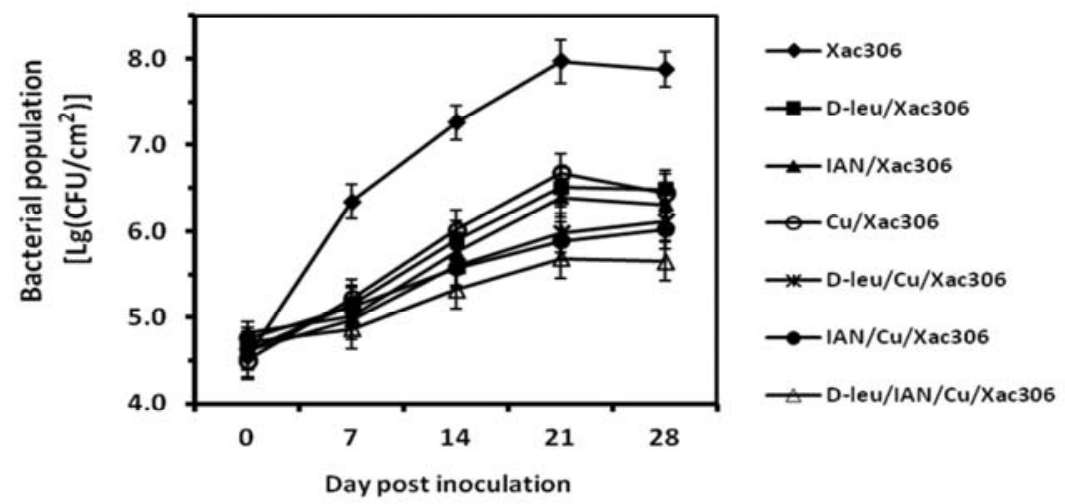

Fig. 5. Effect of D-leucine and 3-indolylacetonitrile (IAN) on Xanthomonas citri subsp. citri strain 306 (Xac 306) infection on citrus leaves. A, D-leucine and IAN reduced canker symptom development on grapefruit leaves spray-inoculated by X. citri subsp. citri strain 306 (approximately $10^{8} \mathrm{CFU} / \mathrm{ml}$ ). Images are representative of four independent replicates at 28 days postinoculation. Xac306: strain 306 alone; D-leu/Xac306: D-leucine (10 mM) inoculated simultaneously with X. citri subsp. citri strain 306; IAN/Xac306: 3-indolylacetonitrile $(100 \mu \mathrm{g} / \mathrm{ml})$ inoculated simultaneously with $X$. citri subsp. citri strain 306 ; D-leu/Xac306 (6 h): D-leucine $(10 \mathrm{mM})$ inoculated $6 \mathrm{~h}$ before $X$. citri subsp. citri strain 306 inoculation; IAN/Xac306 $(6 \mathrm{~h})$ : 3-indolylacetonitrile $(100 \mu \mathrm{g} / \mathrm{ml})$ inoculated $6 \mathrm{~h}$ before $X$. citri subsp. citri strain 306 inoculation; $\mathrm{H}_{2} \mathrm{O}$ : water only; $\mathrm{Cu} / \mathrm{Xac} 306: \mathrm{CuSO}_{4}(100 \mu \mathrm{g} / \mathrm{ml})$ inoculated simultaneously with $X$. citri subsp. citri strain 306; D-leu/Cu/Xac306: D-leucine $(10 \mathrm{mM})$ and $\mathrm{CuSO}_{4}(100 \mu \mathrm{g} / \mathrm{ml})$ inoculated simultaneously with $X$. citri subsp. citri strain 306; IAN/Cu/Xac306: 3-indolylacetonitrile $(100 \mu \mathrm{g} / \mathrm{ml})$ and $\mathrm{CuSO}_{4}(100 \mu \mathrm{g} / \mathrm{ml})$ inoculated simultaneously with $X$. citri subsp. citri strain 306; D-leu/IAN/Cu/Xac306: D-leucine (10 mM), 3-indolylacetonitrile $(100 \mu \mathrm{g} / \mathrm{ml})$ and $\mathrm{CuSO}_{4}(100 \mu \mathrm{g} / \mathrm{ml})$ inoculated simultaneously with X. citri subsp. citri strain 306; Xac306/D-leu (6 h): D-leucine (10 mM)

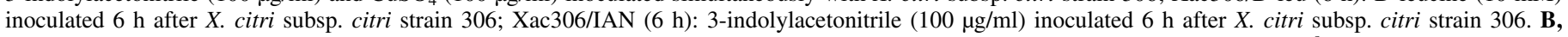
D-leucine and IAN affected the growth of $X$. citri subsp. citri strain 306 populations on grapefruit leaves following spray inoculation ( $\left.10^{8} \mathrm{CFU} / \mathrm{ml}\right)$. Bacterial cells were extracted from the leaves at different time points after inoculation and quantified using the standard serial diluting-plating method. The values shown are means of three repeats and standard deviations. All the assays were repeated three times with similar results. 
(24) recently evaluated small molecule modulators of quorum sensing (QS) for inhibitors of QS-related bacterial virulence and found that four synthetic $N$-acylated L-homoserine lactone (AHL) analogues could attenuate virulence both in Pectobacterium carotovora and Pseudomonas syringae on their hosts potato and green bean. Altogether, our observations along with these reports indicate practical value of using small molecule biofilm formation and/or QS modulators to manage bacterial plant pathogens under field conditions.

D-leucine and IAN appear to have distinct mechanisms of action in reducing biofilm formation by $X$. citri subsp. citri. In this study, we have found that both D-leucine and IAN inhibit the biofilm formation of $X$. citri subsp. citri on different abiotic surfaces and host leaves at sub-MIC concentrations (Fig. 2), while only IAN repressed expression of several biofilm formationrelated genes (chemotaxis/motility-related genes) in $X$. citri subsp. citri (Fig. 3). Flagellar-mediated chemotaxis/motility and type IV pili protein are necessary for $X$. citri subsp. citri biofilm formation (20). The observation of IAN repressing expression of genes related to bacterial motility was consistent with previous reports for IAN effect on biofilm formation in the human bacterial pathogen Pseudomonas aeruginosa (19). Hence, IAN probably reduces $X$. citri subsp. citri biofilm formation by repressing these chemotaxis/motility-related genes (cheY, motB, and pilB) (Fig. 3) and thus reducing its chemotaxis and motility even though we could not rule out other possibilities. Interestingly, it has been documented that the small molecule 2AI could inhibit biofilm formation in the human dental caries pathogen Streptococcus mutans by down-regulating the expression of six biofilm-associated genes (22), while whether 2AI suppresses biofilm formation in X. euvesicatoria using similar mechanism(s) requires further investigation (35). Intriguingly, it has been found that several D-amino acids including D-leucine inhibit biofilm formation in Bacillus subtilis and Staphylococcus aureus by preventing protein localization at the cell surface $(15,17,28)$. Whether D-leucine prevents protein localization at the cell surface of $X$. citri subsp. citri remains to be characterized.

Reduced sensitivity to copper in bacteria may result from genetic mutations and from the change of environmental factors influencing the ionic concentration or production of bacterial extracellular polysaccharides (EPS) that can bind the biologically active ions of copper $(14,16)$. LPS is also known to be a key component of the outer membrane of gram-negative bacteria and a protective barrier against harsh environmental conditions including copper stress (36). It has been shown that decreased sensitivity of bacteria to copper can be mediated by biofilms (27). A synergistic effect was suggested between diffusion barriers to antimicrobial compounds and other mechanisms associated with bacterial resistance including cation/multidrug efflux of the cells in biofilms (27). In our experimental conditions, the results showed that both D-leucine and IAN increased the susceptibility of the $\mathrm{Cu}^{\mathrm{S}}$ (X. citri subsp. citri strain 306) and $\mathrm{Cu}^{\mathrm{R}}$ (X. citri subsp. citri strain A44) $X$. citri subsp. citri planktonic and biofilm cells to copper (Fig. 4), but did not affect expression of genes responsible for gum EPS biosynthesis, LPS O-antigen production, or genes related to copper resistance. It is possible that D-leucine and IAN may affect $X$. citri subsp. citri resistance by suppressing biofilm formation or causing bacteria to remain in a planktonic state making them more sensitive to copper. Similarly, the small molecule 2AI was suggested to decrease the resistance of $X$. euvesicatoria to copper by inhibiting biofilm formation or causing bacteria to remain in a planktonic state making them more sensitive to antibacterial agents (35). Importantly, this is the case in the copper resistance of Pseudomonas aeruginosa and Xylella fastidiosa, where the planktonic cells were more susceptible than biofilm cells $(27,32)$.

Preventive effects of D-leucine and IAN have been demonstrated on X. citri subsp. citri spray-inoculated young citrus plants by foliar spraying. In greenhouse assays, foliar spray applications of D-leucine and IAN, $6 \mathrm{~h}$ pre-inoculation or co-inoculation, reduced the number of lesions produced by $X$. citri subsp. citri and the bacterial populations on grapefruit leaves (Fig. 5). The data obtained suggests that D-leucine and IAN suppress biofilm formation of $X$. citri subsp. citri on host plant surfaces, which may cause impaired infection. Furthermore, the combined application of D-leucine, IAN, and copper enhanced activities against the $X$. citri subsp. citri bacterium compared with the application of copper alone, suggesting an apparent additive effect that may permit a dosage reduction of copper. It would be of great value to decrease the copper usage in the open environment as it reduces the potential for side effects to the environment. Overall, this work validated the potential of pursuing small molecule biofilm inhibitors for managing citrus canker disease.

\section{ACKNOWLEDGMENTS}

This work has been supported by Citrus Research and Development Foundation.

\section{LITERATURE CITED}

1. Alva, A. K. 1993. Copper contamination of sandy soils and effects on young Hamlin orange trees. Bull. Environ. Contam. Toxicol. 51:857-864.

2. Behlau, F., Belasque, J., Jr., Graham, J. H., and Leite, R. P., Jr. 2010. Effect of frequency of copper applications on control of citrus canker and the yield of young bearing sweet orange trees. Crop Prot. 29:300-305.

3. Behlau, F., Canteros, B. I., Jones, J. B., and Graham, J. H. 2012. Copper resistance genes from different xanthomonads and citrus epiphytic bacteria confer resistance to Xanthomonas citri subsp. citri. Eur. J. Plant Pathol. 133:949-963.

4. Behlau, F., Canteros, B. I., Minsavage, G. V., Jones, J. B., and Graham, J. H. 2011. Molecular characterization of copper resistance genes from Xanthomonas citri subsp. citri and Xanthomonas alfalfa subsp. citrumelonis. Appl. Environ. Microbiol. 77:4089-4096.

5. Brunings, A., and Gabriel, D. 2003. Xanthomonas citri: Breaking the surface. Mol. Plant Pathol. 4:141-157.

6. Cubero, J., and Graham, J. H. 2002. Genetic relationship among worldwide strains of Xanthomonas causing canker in citrus species and design of new primers for their identification by PCR. Appl. Environ. Microbiol. 68:1257-1264.

7. da Silva, A. C., Ferro, J. A., Reinach, F. C., Farah, C. S., Furlan, L. R., Quaggio, R. B., Monteiro-Vitorello, C. B., Van Sluys, M. A., Almeida, N. F., Alves, L. M., do Amaral, A. M., Bertolini, M. C., Camargo, L. E., Camarotte, G., Cannavan, F., Cardozo, J., Chambergo, F., Ciapina, L. P., Cicarelli, R. M., Coutinho, L. L., Cursino-Santos, J. R., El-Dorry, H., Faria, J. B., Ferreira, A. J., Ferreira, R. C., Ferro, M. I., Formighieri, E. F., Franco, M. C., Greggio, C. C., Gruber, A., Katsuyama, A. M., Kishi, L. T., Leite, R. P., Lemos, E. G., Lemos, M. V., Locali, E. C., Machado, M. A., Madeira, A. M., Martinez-Rossi, N. M., Martins, E. C., Meidanis, J., Menck, C. F., Miyaki, C. Y., Moon, D. H., Moreira, L. M., Novo, M. T., Okura, V. K., Oliveira, M. C., Oliveira, V. R., Pereira, H. A., Rossi, A., Sena, J. A., Silva, C., de Souza, R. F., Spinola, L. A., Takita, M. A., Tamura, R. E., Teixeira, E. C., Tezza, R. I., Trindade dos Santos, M., Truffi, D., Tsai, S. M., White, F. F., Setubal, J. C., and Kitajima, J. P. 2002. Comparison of the genomes of two Xanthomonas pathogens with differing host specificities. Nature 417:459-463.

8. Gottig, N., Garavaglia, B. S., Garofalo, C. G., Orellano, E. G., and Ottado, J. 2009. A filamentous hemagglutinin-like protein of Xanthomonas axonopodis pv. citri, the phytopathogen responsible for citrus canker, is involved in bacterial virulence. PLoS ONE 4:e4358.

9. Gottwald, T. R., Graham, J. H., Bock, C., Bonn, G., Civerolo, E., Irey, M., Leite, R., McCollum, G., Parker, P., Ramallo, J., Riley, T., Schubert, T., Stein, B., and Taylor, E. 2009. The epidemiological significance of postpackinghouse survival of Xanthomonas citri subsp. citri for dissemination of Asiatic citrus canker via infected fruit. Crop Prot. 28:508-524.

10. Gottwald, T. R., Graham, J. H., and Schubert, T. S. 2002. Citrus canker: The pathogen and its impact. Plant Health Prog. Online. doi:10.1094/ PHP-2002-0812-01-RV

11. Graham, J. H., Dewdney, M. M., and Myers, M. E. 2010. Streptomycin and copper formulations for control of citrus canker on grapefruit. Proc. Florida State Horticultural Society 123:92-98.

12. Graham, J. H., Gottwald, T. R., Cubero, J., and Achor, D. S. 2004. Xanthomonas axonopodis pv. citri: Factors affecting successful eradication of citrus canker. Mol. Plant Pathol. 5:1-15. 
13. Guo, Y., Sagaram, U. S., Kim, J. S., and Wang, N. 2010. Requirement of the galU gene for polysaccharide production by and pathogenicity and growth in planta of Xanthomonas citri subsp. citri. Appl. Environ. Microbiol. 76:2234-2242.

14. Hasman, H., Bjerrum, M. J., Christiansen, L. E., Hasen, H. C. B., and Aarestrup, F. M. 2009. The effect of $\mathrm{pH}$ and storage on copper speciation and bacterial growth in complex media. J. Microbiol. Method 78:20-24

15. Hochbaum, A. I., Kolodkin-Gal, I., Foulston, L., Kolter, R., Aizenberg, J., and Losick, R. 2011. Inhibitory effects of D-amino acids on Staphylococcus aureus biofilm development. J. Bacteriol. 193:5616-5622.

16. Hsiao, Y., Liu, Y., Lee, P., Hsu, P., Tseng, S., and Pan, Y. 2011. Functional characterization of copA gene encoding multicopper oxidase in Xanthomonas campestris pv. campestris, J. Agric. Food Chem. 59:9290-9302.

17. Kolodkin-Gal, I., Romero, D., Cao, S., Clardy, J., Kolter, R., and Losick, R. 2010. D-amino acids trigger biofilm disassembly. Science 328:627-629.

18. Laia, M., Moreira, L., Dezajacomo, J., Brigati, J., Ferreira, C., Ferro, M., Silva, A., Ferro, J., and Oliveira, J. 2009. New genes of Xanthomonas citri subsp. citri involved in pathogenesis and adaptation revealed by a transposon-based mutant library. BMC Microbiol. 9:12.

19. Lee, J. H., Cho, M. H., and Lee, J. 2011. 3-Indolylacetonitrile decreases Escherichia coli O157:H7 biofilm formation and Pseudomonas aeruginosa virulence. Environ. Microbiol. 13:62-73.

20. Li, J., and Wang, N. 2011. Genome-wide mutagenesis of Xanthomonas axonopodis pv. citri reveals novel genetic determinants and regulation mechanisms of biofilm formation. PLoS ONE 6:e21804.

21. Li, J., and Wang, N. 2012. The gpsX gene encoding a glycosyltransferase is important for polysaccharide production and required for full virulence in Xanthomonas citri subsp. citri. BMC Microbiol. 12:31.

22. Liu, C., Worthington, R. J., Melander, C., and Wu, H. 2011. A new small molecule specifically inhibits the cariogenic bacterium Streptococcus mutans in multispecies biofilms. Antimicrobiol. Agents. Chemother. 55:2679-2687.

23. Livak, K., and Schmittgen, T. 2001. Analysis of relative gene expression data using real-time quantitative PCR and the 2-DeltaDeltaCT method. Methods 25:402-408

24. Palmer, A. G., Streng, E., and Blackwell, H. E. 2011. Attenuation of virulence in pathogenic bacteria using synthetic quorum-sensing modulators under native conditions on plant hosts. ACS Chem. Biol. 6:1348-1356.

25. Rigano, L. A., Siciliano, F., Enrique, R., Sendin, L., Filippone, P., Torres, P. S., Questa, J., Dow, J. M., Castagnaro, A. P., Vojnov, A. A., and Marano, M. R. 2007. Biofilm formation, epiphytic fitness, and canker development in Xanthomonas axonopodis pv. citri. Mol. Plant-Microbe Interact. 20:1222-1230.

26. Ritchie, D. F., and Dittapongpitch, V. 1991. Copper- and streptomycin- resistant strains and host differentiated races of Xanthomonas campestris pv. vesicatoria in North Carolina. Plant Dis. 75:733-736.

27. Rodrigues, C. M., Takita, M. A., Coletta-Filho, H. D., Olivato, J. C. Caserta, R., Machado, M. A., and de Souza, A. A. 2008. Copper resistance of biofilm cells of the plant pathogen Xylella fastidiosa. Appl. Microbiol. Biotechnol. 77:1145-1157.

28. Romero, D., Vlamakis, H. Losick, R., and Kolter, R. 2011. An accessory protein required for anchoring and assembly of amyloid fibers in $B$. subtilis biofilms. Mol. Microbiol. 80:1155-1168.

29. Rybak, M., Minsavage, G. V., Stall, E., and Jones, J. B. 2009. Identification of Xanthomonas citri subsp. citri host specificity genes in a heterologous expression host. Mol. Plant Pathol. 10:249-262.

30. Schaad, N., Postnikova, E., Lacy, G., Sechler, A., Agarkova, I., Stromberg, P., Stromberg, V., and Vidaver, A. 2006. Emended classification of xanthomonad pathogens on citrus. Syst. Appl. Microbiol. 29:690-695.

31. Shiotani, H., Uematsu, H., Tsukamoto, T., Shimizu, Y., Ueda, K., Mizuno, A., and Sato, S. 2009. Survival and dispersal of Xanthomonas citri pv. citri from infected Satsuma mandarin fruit. Crop Prot. 28:19-23.

32. Teitzel, G. M., and Parsek, M. R. 2003. Heavy metal resistance of biofilm and planktonic Pseudomonas aeruginosa. Appl. Environ. Microbiol. 69:2313-2320

33. Teixeira, E. C., Franco de Oliveira, J. C., Marques Novo, M. T., and Bertolini, M. C. 2008. The copper resistance operon copAB from Xanthomonas axonopodis pathovar citri: Gene inactivation results in copper sensitivity. Microbiology 154:402-412.

34. Vauterin, L., Hoste, B., Kersters, K., and Swings, J. 1995. Reclassification of Xanthomonas. Int. J. Syst. Bacteriol. 45:472-489.

35. Worthington, R. J., Rogers, S. A., Huigens, R. W., III, Melander, C., and Ritchie, D. F. 2012. Foliar applied small molecule that suppresses biofilm formation and enhances control of copper-resistant Xanthomonas euvesicatoria on peppers. Plant Dis. 96:1638-1644.

36. Yan, Q., Hu, X., and Wang, N. 2012. The novel virulence-related gene $n l x A$ in the lipopolysaccharide cluster of Xanthomonas citri ssp. citri is involved in the production of lipopolysaccharide and extracellular polysaccharide, motility, biofilm formation and stress resistance. Mol. Plant Pathol. 13:923-934.

37. Yan, Q., and Wang, N. 2011. The ColR/ColS two-component system plays multiple roles in the pathogenicity of the citrus canker pathogen Xanthomonas citri subsp. citri. J. Bacteriol. 193:1590-1599.

38. Yan, Q., and Wang, N. 2012. High-throughput screening and analysis of genes of Xanthomonas citri subsp. citri involved in citrus canker symptom development. Mol. Plant-Microbe Interact. 25:69-84.

39. Zhu, B., and Alva, A. K. 1993. Trace metal and cation transport in a sandy soil with various amendments. Soil Sci. Soc. Am. J. 57:723-727. 